Article

\title{
Morphological Evolution of the Port-City Interface of Algiers (16th Century to the Present)
}

\author{
Khalil Bachir Aouissi ${ }^{1}$, Said Madani ${ }^{1}$ and Vincent Baptist ${ }^{2, *}$ \\ ${ }^{1}$ Laboratory PUViT, Ferhat Abbas University Setif 1, Algeria; E-Mails: aouissikhalil@univ-blida.dz (K.B.A.), \\ smadani@univ-setif.dz (S.M.) \\ 2 Erasmus School of History, Culture and Communication, Erasmus University Rotterdam, The Netherlands; \\ E-Mail: baptist@eshcc.eur.nl \\ * Corresponding author
}

Submitted: 17 January 2021 | Accepted: 27 March 2021 | Published: 27 July 2021

\begin{abstract}
This article traces the centuries-long morphological development of Algiers' port-city interface across four historically relevant time periods that together span from the dawn of the 16th century up until today. Through a diachronic and geohistorical approach, we identify and analyse the origins of Algiers' persistent port-city divide. In doing so, the notion of the interface is interpreted as a spatial threshold between city and port, which nevertheless supports the material flows of both entities. As a multi-purpose area, the interface holds the potential to weave the disparate entities of a port city back together. To further complement this conceptual angle, we provide investigations of porosity that determine the differing degrees of connectivity between the city and port of Algiers. This is combined with a spatial-functional analysis of Algiers' current port-city interface, which is ultimately characterised as a non-homogeneous entity composed of four distinct sequences. These results contribute to a better orientation of imminent plans for waterfront revitalisations in Algiers. Whereas the interface was long considered as some kind of no man's land in the past, port and municipal authorities nowadays aim to turn the interface into a tool of reconciliation, and can do so by acting upon its potential porosity. Finally, this article's critical examination of the previously neglected case of Algiers can and should also be considered as an applicable model for the continuing study of southern Mediterranean and African port metropolises in general, which share a particular evolution in the relations between city and port.
\end{abstract}

\section{Keywords}

Algiers; flows; Kasbah; porosity; port-city interface; waterfront

\section{Issue}

This article is part of the issue "Planning for Porosity: Exploring Port City Development through the Lens of Boundaries and Flows" edited by Carola Hein (Delft University of Technology, The Netherlands).

(C) 2021 by the authors; licensee Cogitatio (Lisbon, Portugal). This article is licensed under a Creative Commons Attribution 4.0 International License (CC BY).

\section{Introduction}

Between land and sea, at the convergence of two different spheres of flows, port cities can be qualified as interfaces between a foreland and a hinterland that generate crossroad connections on an intercontinental scale (Chaline, 1994). Regarded as "centres of exchange where different cultures and different environments meet" (Tan, 2007, p. 852), port cities are themselves composed of an urban entity and a port entity. The buffer space between the two is defined as the port-city interface (Boubacha et al., 1997; Hayuth, 1982; Hoyle, 1989, 2000). As a median space, this interface materialises the legal boundaries between city and port, but also ensures the interlocking of the urban and port system and their overlapping interests, thus becoming an area of simultaneous cooperation and conflict, or convergence and divergence. Any contrast between land and sea, and between city and port, is played out on this median part, hence the importance of studying port-city interfaces 
in particular detail and within historical contexts (Hein, 2020). Technological developments of transport can be considered as the main factor in the evolution of maritime flows and global economic transformations, which have resulted in the metamorphosis of port-city interfaces around the world. In this regard, the industrial revolution has been a milestone for changes in the port-city relationship, passing from a clear-cut spatial interconnection to a complex, interwoven system. In the face of this drastic development, the port-city interface has likewise passed from a simple public zone to an intricate and porous space. It emerges as a transformative space, onto which strategies of recomposition and renewal are applied, through confrontation, consultation, or collaboration (Boubacha, 1997). In this sense, the interface does not simply separate, but also has the ability to 'weave together' the various entities that comprise a port city.

In having their own diachronic and synchronic developments, and responding to the social, economic, and environmental contexts that surround them, port cities across the world are not necessarily different from other kinds of cities. However, a set of shared key characteristics does make port cities stand out as a distinct urban category in analyses (Chaline, 1994). The first common element is of course the presence of the port itself, which imposes a particular spatial configuration onto the city and simultaneously connects it to a transnational network of fellow cities. Secondly, the evolutionary chronology of port cities generally distinguishes two major urban phenomena that have propelled these maritime hubs from the pre-industrial to the industrial and postindustrial era. The first phenomenon in this case, the port-city split or divide (Boubacha et al., 1997; Chaline, 1999), is a consequence of the industrial revolution in the 19th century. The second phenomenon, waterfront revitalisations (Hoyle, 1989, 2000; Hoyle \& Pinder, 1992), is an antipode to this, serving as a response to the rise of the tertiary sector in cities since the 1950s. Both events have strongly influenced the urban form of port cities through their direct impact on the port-city interface.

In the pre-industrial era, maritime trade flows were ensured by rudimentary means of transportation such as wooden ships, whereby the rotation between different flows of goods would take up days. Back then, the port was mostly an artificial extension of the city into the sea (Aouissi, 2016). Port activity complemented urban activity, and one would therefore talk about 'the city and its port' in unison. This also expresses the significant levels of porosity and permeability that existed between city and port then, as both were not developed enough yet to even be regarded as entirely separate entities. It begs the question to what extent this kind of historical congruence is still traceable in the oldest foundations of port cities and their interfaces nowadays. After all, due to considerable technical advances in terms of the mobility of resources and the mass production of goods, the industrial revolution subsequently engendered global market shifts. The mechanisation of production processes gen- erated excess quantities of products, which helped contribute to the expansion of trade. The new industrialeconomic base thus essentially started to depend on the transfer flows of goods, hence the need for new means of transportation such as railways on the land and new steam and motor ships at sea (Bird, 1963).

Faced with this new situation, ports became economic actors of primary importance. The double-sided position of ports proved itself as a real catalyst of exchange: enhanced connections on the land endowed the port with a larger hinterland, while the maritime sphere became faster navigable and started to offer a greater range of actions. Furthermore, with the increasing establishment of factories and warehouses close to the port and its adjacent railway infrastructures, the notion of the port took on an even more industrial meaning. This new status ensured that the port was no longer considered as simply a district of its city, but as a true infrastructural complex in its own right and with a regional scale of direct connectivity. The conceptual understanding of 'the city and its port' changed into that of 'the port and its region'. The physical expansion and distancing of the port became accompanied by a weakening relationship with and accessibility to the city (Hayuth, 1982; Schubert, 2018). Within urban geography, planning, and sociology, this particular development has sometimes been considered as an urban scourge or crisis of sorts. Detailed investigations of port-city interfaces in specific contexts, like the one provided in this article, can help track down to what extent this problematic development still affects the interlinkages between city and port today.

During the 20th century, with the globalisation of trade firmly under the influence of mass production, the situation of the port-city split continued to be accentuated (Hall \& Jacobs, 2010). Additionally, the means for maritime transport became more extensive and demanding in terms of the space needed for technical equipment and wider quays. In this way, the port-city interface evolved through an increasingly thick and opaque physical materialisation: next to railways, the development of roads further filled up this buffer zone, in positive correlation with the continued importance of land transport (see Figure 1). Nevertheless, with the rise of containerisation deepening the port-city split in the mid20th century (Hoyle et al., 1988; Schubert, 2018), the abandonment of port sites most closely located to city centres also resulted in the new urban phenomenon of waterfront revitalisations that profoundly modified the interface areas again (Aouissi, 2016; Porfyriou \& Sepe, 2017). Industrial storage terrains, and locations strongly connected to transport infrastructure that fell out of use, became favourable grounds for large urban transformation operations, with cities like Baltimore, Barcelona, or Lisbon offering some of the most illustrative cases in this regard (Aouissi, 2019; Sánchez \& Daamen, 2020). Often seen as some sort of panacea for the break-up between cities and ports, the question remains whether 


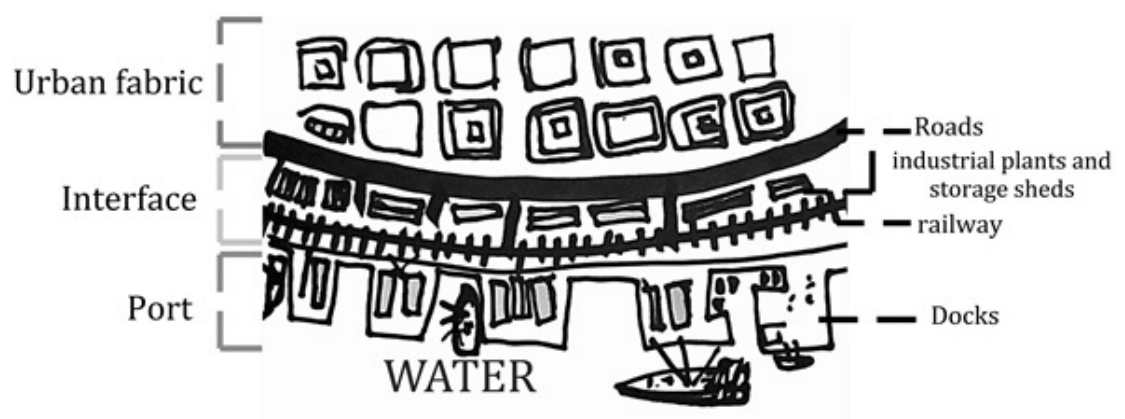

Figure 1. Illustrative diagram of the spatial split between city and port, with the separating interface as buffer zone. Source: Amended by the authors, based on Wrenn (1983).

waterfront revitalisation plans are also able to overthrow the traditional industrial density of the port-city interface in non-Western maritime hubs, which often drag along a different trajectory of urban evolution.

If the origins of the port-city split were directly linked to the industrial revolution for European and American cities, the urban phenomenon also further manifested itself globally and affected non-Western port cities, through the increased colonisation of Africa and Asia that started in the 19th century. Yet, as one might expect, the predominant focus in scholarly literature is put on Western as well as contemporary East Asian port contexts, and thereby often foregoes significant differences and historical nuances that are at play in port cities in other parts of the world (Akhavan, 2020). To help alleviate this persisting imbalance, Algiers has been chosen as a pertinent case study that needs further exploration, since, firstly, very few studies so far have dealt with aspects of port-city relationships, and particularly the interface, in this North-African capital over the course of its history. Secondly, Algiers currently finds itself in a situation with a very pronounced port-city divide, and is blatantly lagging behind on issues related to port-city relations within the larger Mediterranean context that it is part of (Aouissi, 2016). This necessitates further analyses that can contribute to a better orientation of future port reconversion plans. Finally, this article's critical examination of the case of Algiers can and should also be considered as an applicable model for the continuing study of southern Mediterranean and African port metropolises in general, which experienced a period of colonisation and subsequent waves of independence during the last century. As such, port cities in these less developed countries share a particular evolution in the relations between city and port, as well as in the morphology of their port-city interfaces. Especially in the case of Algiers, the port-city interface not merely functions as a physical separator, but is also highly illustrative of a mental dichotomy or value-based clash between urban interests that focus on the comfort of city inhabitants and port interests that concern economic efficiency. The city and the port thus influence each other in paradoxical and negative ways, thereby turning their shared interface into the spatial concretisation of a conflicting situation.
With a focus on these circumstances, the port city of Algiers is specifically considered as an amphibian creature throughout this article, whereby the interface can weave together different types of zones and levels of porosity. This is already due to Algiers' original morphological configuration: With the hills of Bouzaréah forming a shelter to the dominant northwest winds while overlooking the central bay area, and a set of islets connecting to the mainland, everything is favourable for Algiers to be considered as a naturally shaped port (Ravéreau, 2007). Historically, this also motivated the construction, by the Phoenicians in the 4th century BC, of the city of Icosium by the sea (Camps et al., 1986), in the same area that later housed the famous Kasbah of Algiers. While the word 'Kasbah' designates an urban entity that makes up the old city of Algiers, especially as it is assimilated through the population's imagination nowadays, it simultaneously refers to a particular period in the city's history that spans more than three centuries, from its capture by the Ottoman privateer brothers Arudj and Khayr ad-Din Barberousse in 1516 until the start of the French colonisation in 1830 . Since then, through its military and geostrategic importance, Algiers experienced a series of changes that have become reflected in the spatial configuration of its port-city interface. In this respect, the purpose of this article is to map, dissect, and understand the material and immaterial evolution of the flows and related porosity characteristics dictating this portcity interface and their varying impacts on Algiers' urban form, from the age of the Kasbah to its contemporary metropolitan context.

\section{Methods}

This study combines historical and geographical approaches into one axial method that crosses temporal and spatial scales (Braudel, 1949), in order to explain the changing composition of the port city territories under investigation. This procedure allows to reconstruct both the structure and dynamics of Algiers' port-city interface, while providing a diachronic perspective of the landscape (Jacob-Rousseau, 2009). More specifically, our case study describes the evolution of Algiers' urban and port history through events that cross both domains, 
notably economic and political events, and their material and immaterial translations at the level of the port-city interface. Our research relies on cartographic archival material, graphic representations, and written testimonies, in particular the historical descriptions of Diego de Haëdo (1612/1998) that predate the French colonisation period and the cartographic reconstructions of Roger Meunier (1961). In addition, the remarkable thesis of René Lespès (1921) is also of primary importance to us, as it originated from a request of the municipality of Algiers to introduce major projects of urban expansion that were to be conducted in semblance with European counterparts (Bernard, 1931).

Based on these historical sources, and together with more contemporary references, this article first constructs an overview of Algiers and its port before the French colonisation. Subsequently, the period of colonisation, commonly known as one with great upheavals and transformations for the port-city interface, is investigated in two parts. Finally, we look at the development of Algiers' port-city relations from the national independence starting in 1962 up to today. The adopted geohistorical approach allows us to focus on key moments in Algiers' urban evolution and their particular impact on the port-city interface. This work adds to the understanding of the interface as a multi-purpose area and a concrete spatial threshold between city and port (Moretti, 2018), while nevertheless providing infrastructural support for the material flows of both entities. To further complement this conceptual angle, we provide accompanying investigations of porosity. By calculating and interpreting the void ratios of the urban walls in relation to the interface, the differing degrees of connectivity between the city and port of Algiers are determined.

In this way, it becomes possible to better identify and analyse the origins of the contemporary dichotomy between city and port, as mentioned above. With a better understanding of the root causes of the port-city interface's shape, we construct a spatial-functional analysis of the current territory. By considering in this way how fluctuating flows and porosity structure and determine the stakes between city and port, we formulate the continuing influence and dynamics between both entities more accurately. Ultimately, this is considered as a necessary step towards a more holistic diagnosis and a better orientation of upcoming action proposals for the inevitable revitalisation processes of the Algiers waterfront (Aouissi, 2019).

\section{Findings and Results}

The sea has always shaped the city of Algiers. It originally arose from an ancient Phoenician trading post, which found all the assets it needed in the direct natural environment (see Figure 2): shelter against the regular winds, a strategic hilltop from where to dominate the surroundings, and accessible and abundant water sources. "Algiers is nothing less than a natural port" (Bérard, 1837, p. 91; authors' translation): this was the opinion of Lieutenant-Commander Bérard, to whom we

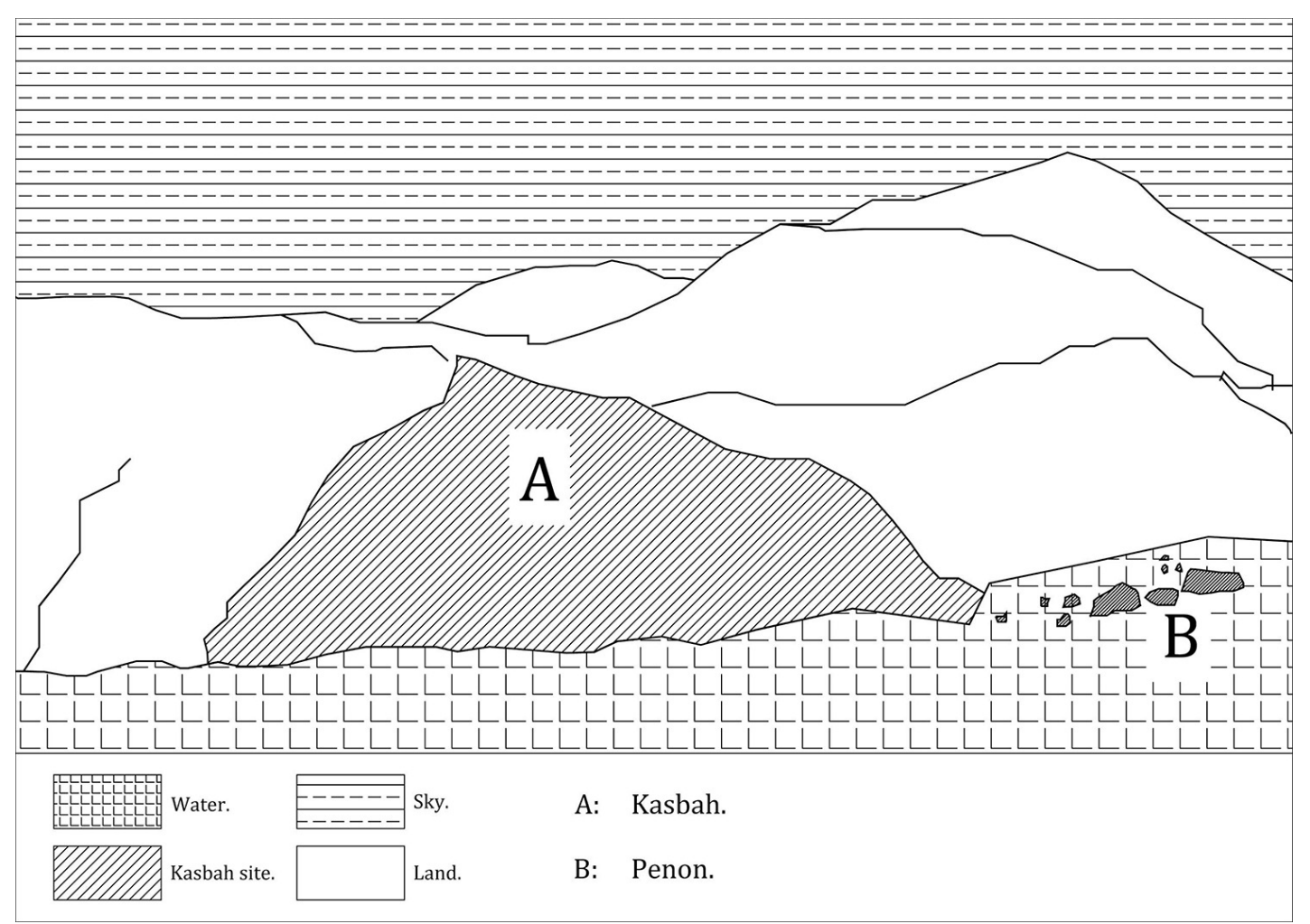

Figure 2. Frontal view of the natural landscape surrounding the original Kasbah site. Source: Produced by the authors, based on Meunier (1961). 
owe the first nautical description of the Algerian coasts. Since the birth of the city, a series of events has significantly punctuated its urban history and shaped its form, resulting in a range of dialectical metamorphoses for the port-city interface in particular. From the first formation of the inner Kasbah city until Algiers' coming into being as a modern metropolis half a millennium later, we distinguish four historically relevant time periods, on the basis of notable urban or port-related transformations involving changes in the flows, porosity and morphology of the port-city interface, and which are related to major historical and economic events.

\subsection{The Interface during the Kasbah (1529-1830)}

The capture of Algiers by the Ottoman brothers Barberousse dates back to 1516 . However, Algiers could not be considered a port city at that point in time, as the port simply did not exist yet (Meunier, 1961). Back then, a group of four main islets located very close to the city coast formed the 'Penon of Algiers' (see Figure 2). The Penon was initially under control of a garrison of the Spanish Empire, which settled there by building a fortress in 1510 (Chérif, 2010). In 1529, the Barberousses took over the Penon and launched a series of colossal backfill works to connect all islets to the city's coastline (see Figure 3). A dike was formed that has kept its original name, the 'Khayr ad-Din Barberousse pier,' up until today. As the earliest created form of the port, the newly connected territory provided a surface area of four hectares and a capacity to accommodate 70 small ships, mainly used by privateers to supply larger ships that were berthed offshore and could not yet reach the port due to the insufficient depth offered by the harbour (Meunier, 1961).

In this period, the port was a base for privateers active in the region, who brought Algiers to life under a new regency. This 'golden age' period was characterised

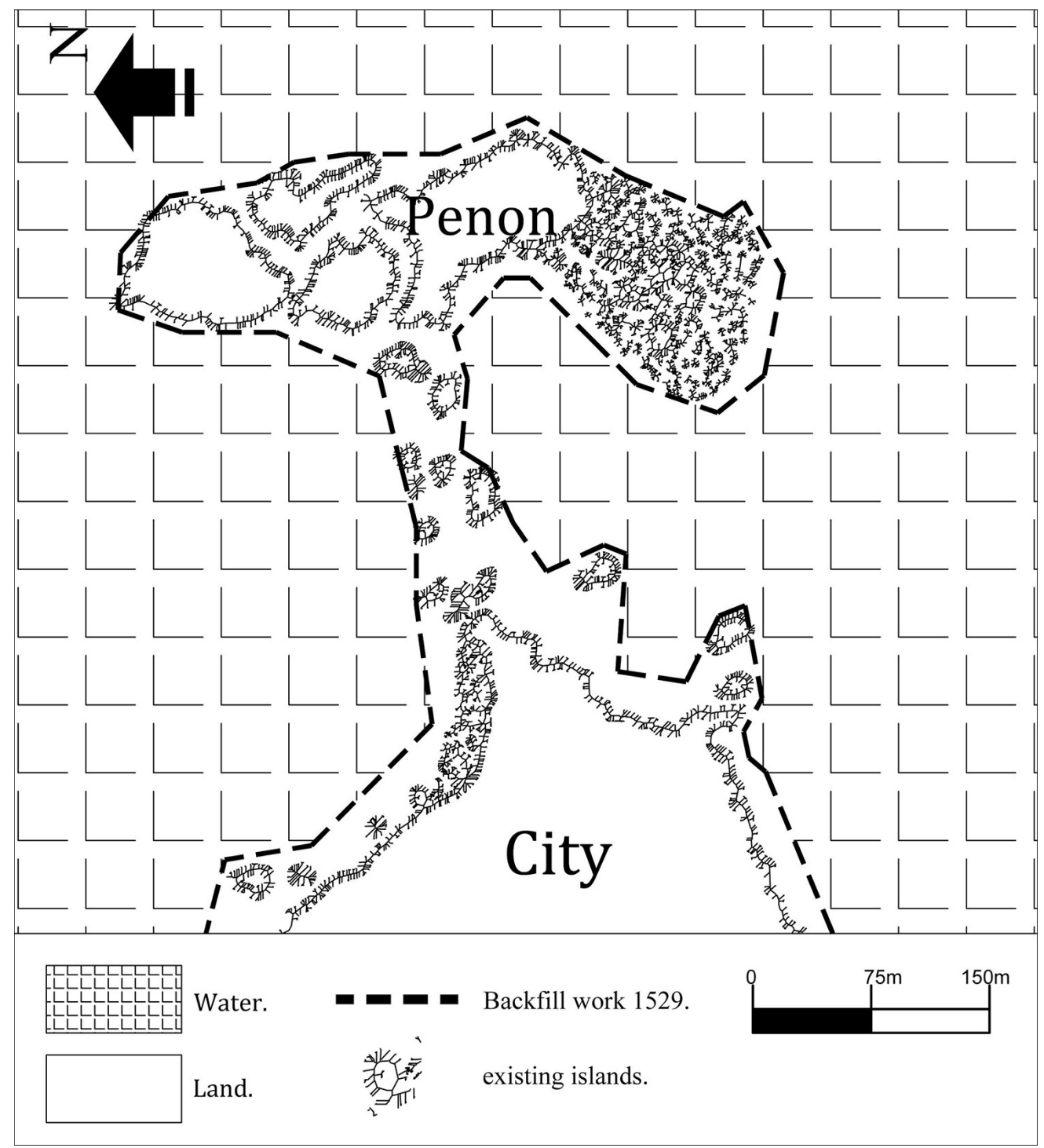

Figure 3. Map of the Penon and the city before 1529, providing an overview of the connecting backfill works that were carried out. Source: Produced by the authors, based on Meunier (1961). 
by an electrified atmosphere in the Mediterranean, particularly between Muslims and Christians. Algiers' principal concern at the time was its protection against European rivals. The port sheltered a formidable social class of pirates, known as the 'Taïfa des Raïs.' All representations and written sources related to this time depict the port of Algiers as a fortress and a first line of defense, standing in front of the actual city walls that were endowed with loopholes for cannons. Already in this earliest context, then, a strategic interface materialised as mediating space between city and port.

Apart from the slave trade, for which Algiers became a crucial market (de Haëdo, 1612/1998), trade and commercial exchange were not yet of primary importance to the port. Most commercial exchanges were meagre and limited to the import of exotic and expensive materials, such as Italian marble for the palaces of the Kasbah, for example. Fishing, on the other hand, was a vital source of income for city inhabitants. Consequently, large parts of Algiers' population were characterised as fishermen. This economic function of the city has been kept until today, with the eastern part of the port denoted as the fishery (Aouissi, 2016). Nevertheless, the main role of the port of Algiers was taken up by its supreme naval force back then (Belhamissi, 1986). The port of Algiers became profitable as a maritime base for privateers, by imposing taxes on various fleets entering the Mediterranean in exchange for protection against pirate ships and third-party attacks (Lespès, 1921).

The communication between city and port was ensured by two gates in the front rampart that fortified the pyramid-shaped perimeter of the city. The first gate, called 'Bab el Bhar' or gate of the sea or the fish, was used by local fishermen to access the beach (Missoum, 2003). The second gate, called 'Bab el Djazira' or island gate, was more important and used as a crossing point to control the incoming and outgoing flows of goods to and from the port. Between the two, a transverse street was built, giving birth to the Lower Kasbah. It could best be considered as a space for the exchange of flows, and it thus defined an interface between city and port. In spatial terms, this crossing clearly belonged within the walls of the inner city, but its functioning largely depended on the port. The historical importance of the district that grew around it is exactly due to its location as an interface or median space, as acknowledged by the location of the city's administrative, financial, and commercial centres.

On the basis of traditional descriptions, the entire interface can be divided into two parts (see Figure 4). The first one, the east side of the Lower Kasbah, links the city gate Bab Azoun to Bab el Djazira. Its function is essentially commercial, by providing services intended for the daily lives of city inhabitants, which is also reinforced by the cross-connection to Bab el Bhar where fishermen sell their harvests. The second, western part, approximately going from Bab el Bhar to Bab el Oued, is known as the Navy District or Marine Quarter and overlooks the port (Missoum, 2003). A part of it that still exists, namely the
Bastion 23 that is also known as the 'Palais des Raïs,' was classified as universal heritage in 1991. This part of the interface was directly aligned with the interests and activities of the port at the time, sheltering luxurious residences for privateers, places of worship, as well as military and maritime factories. The entire interface was thus made up of two parts that not only reflected the dual vocation of Algiers as a port city, but also the hierarchical division of its population. While the eastern part was dedicated to the more plebeian public, the western part was reserved for more distinctive social classes and the elite. These two parts of the interface were distinct, but they also necessarily complemented each other, thereby ensuring the interconnection between city and port. During this first historical phase, Algiers and its port already formed a homogeneously operating entity, whose role was significantly enhanced by an interface that served the spatial and functional mediations between the port city's two spheres.

\subsection{The Interface during the First Period of Colonisation (1830-1848)}

As France was seeking to impose its power more in the south of the Mediterranean, which was mostly controlled by Ottoman fleets until then, the capture of Algiers in 1830 proved to be the ultimate strategic opportunity for French domination on these southern shores. The port of Algiers accentuated its military vocation as a desired French naval base, comparable to that of Toulon (Djedouani-Rakem, 2004). The arrival of the French marked the end of the Ottoman-Turkish period, with the Kasbah being the fruit of three centuries of that occupation. The brutal installation of the French colonial regime changed the morphology of Algiers in a spectacular way (Çelik, 1997), especially with the almost complete destruction of the Lower Kasbah. Outside of the ramparts, a purely technical choice was made to extend the southeastern part of the bay (see Figure 5). The city subsequently simply followed, and grew at the same pace as its extended port (Aouissi, 2016).

While the part of the Navy District up to the 'Palais des Raïs' was preserved, the superimposition of a new urban typology on the Lower Kasbah brought about an important metamorphosis to its overall shape as a port-city interface. The realisation of the new dock in the southeast contributed to the increasing physical distancing between the urban fabric and the seaside by offering more space for the interface itself, which consequently became a more dilated entanglement between the port and city boundaries. Previously characterised through the presence of housing that ultimately got destroyed, the interface took on a new shape. As this change resulted in a withdrawal of the interface, the Navy District also started to lose its role in particular port interests. These transformations further materialised in a concrete way, namely through the insertion of a new public space, the government square, which has ensured 


\section{COGITATIO}

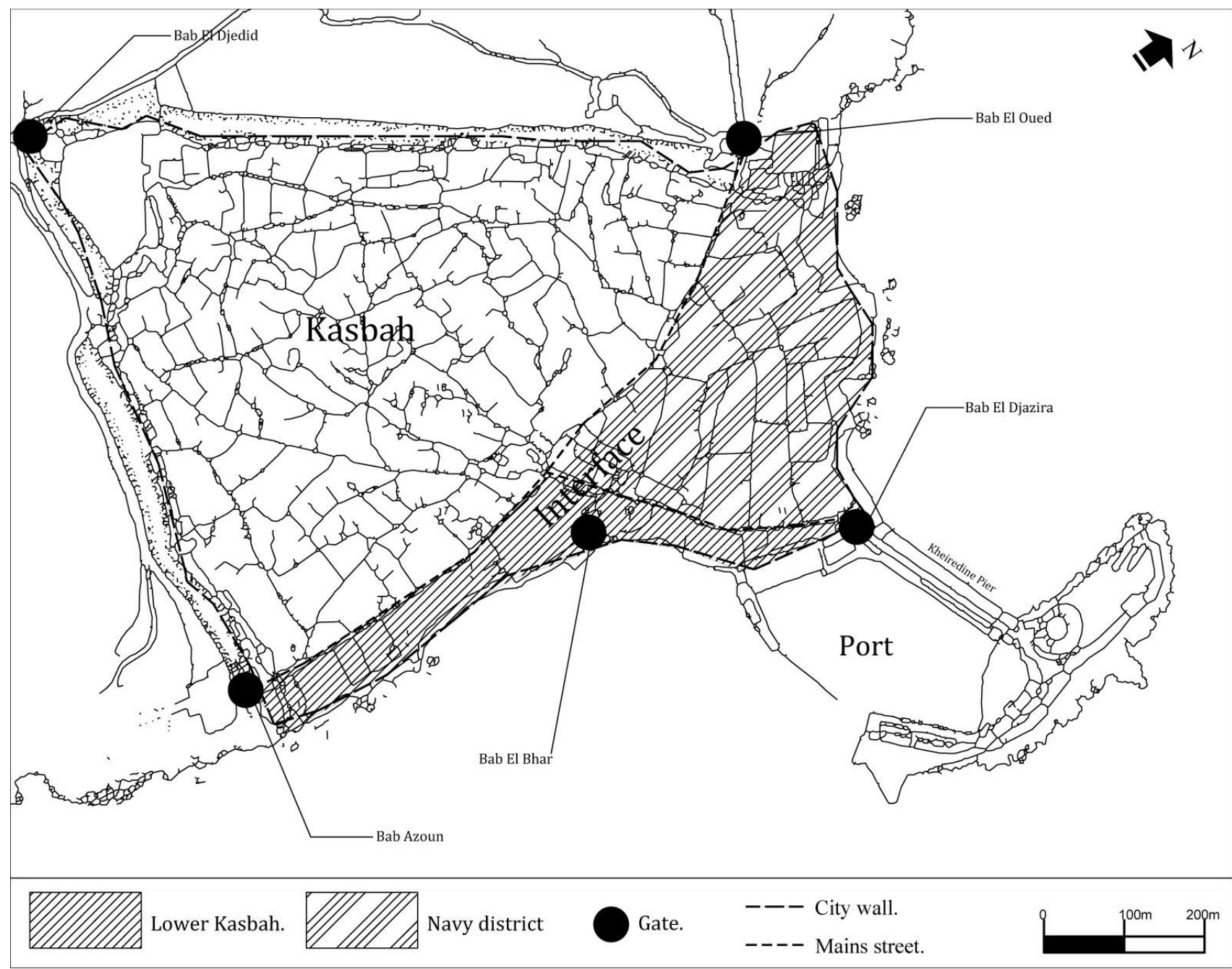

Figure 4. Map (1830) of the divisions of the port-city interface in relation to the principal city gates. Source: Produced by the authors, based on Lespès (1921) and Missoum (2003).

the connections between the newly built dock, the new European extensions of the city, and the rest of the original Kasbah area (see Figure 5).

\subsection{The Interface during the Transition from the Military to the Tertiary Sector (1848-1962)}

As a gateway to Africa, filled with agricultural assets and mining sources, Algeria aroused the economic interests of industrial France (Zimmermann, 1896). Algiers became a point of diffusion for the larger colonisation movement and thus also a valuable ground for investments, as witnessed by the realisation of urban planning projects through the pivotal Guiauchain plan from 1846 onwards. Initially however, this plan for the urban development and expansion of Algiers did not yet give any particular importance to the port. It was first simply enlarged through the basin of the old port between 1848 and 1867, primarily for military purposes (Djedouani-Rakem, 2004). After this phase, however, the development of the port gradually started to gain more importance, as commercial interests began to take precedence over military ones. This was firstly due to the disappearance of real military rivals after the gradual dissolution of the Ottoman Empire. Secondly, it was due to the continued progress of French colonisation in the hinterland, and to the exploitation of available raw materials that put France in a position of full industrial and economic bloom. As a rich source for agricultural products, the Mitidja plain on the outskirts of Algiers, and comprising such satellite towns as Blida, Boufarik, Medea, and Miliana, formed the hinterland of the port city to which it mainly was connected through roads and railways.

Because of these rising economic interests, Algiers quickly developed into a true transfer or relay city. This situation was stimulated by a particular series of events, of which the vast destruction of French vineyards by a phylloxera pest in 1878 was one of the most essential. The resulting crisis contributed to increasing exports of Algerian wines from the Mitidja plain via the port of Algiers to the European continent. As a consequence, the development of both port and city accelerated, as 


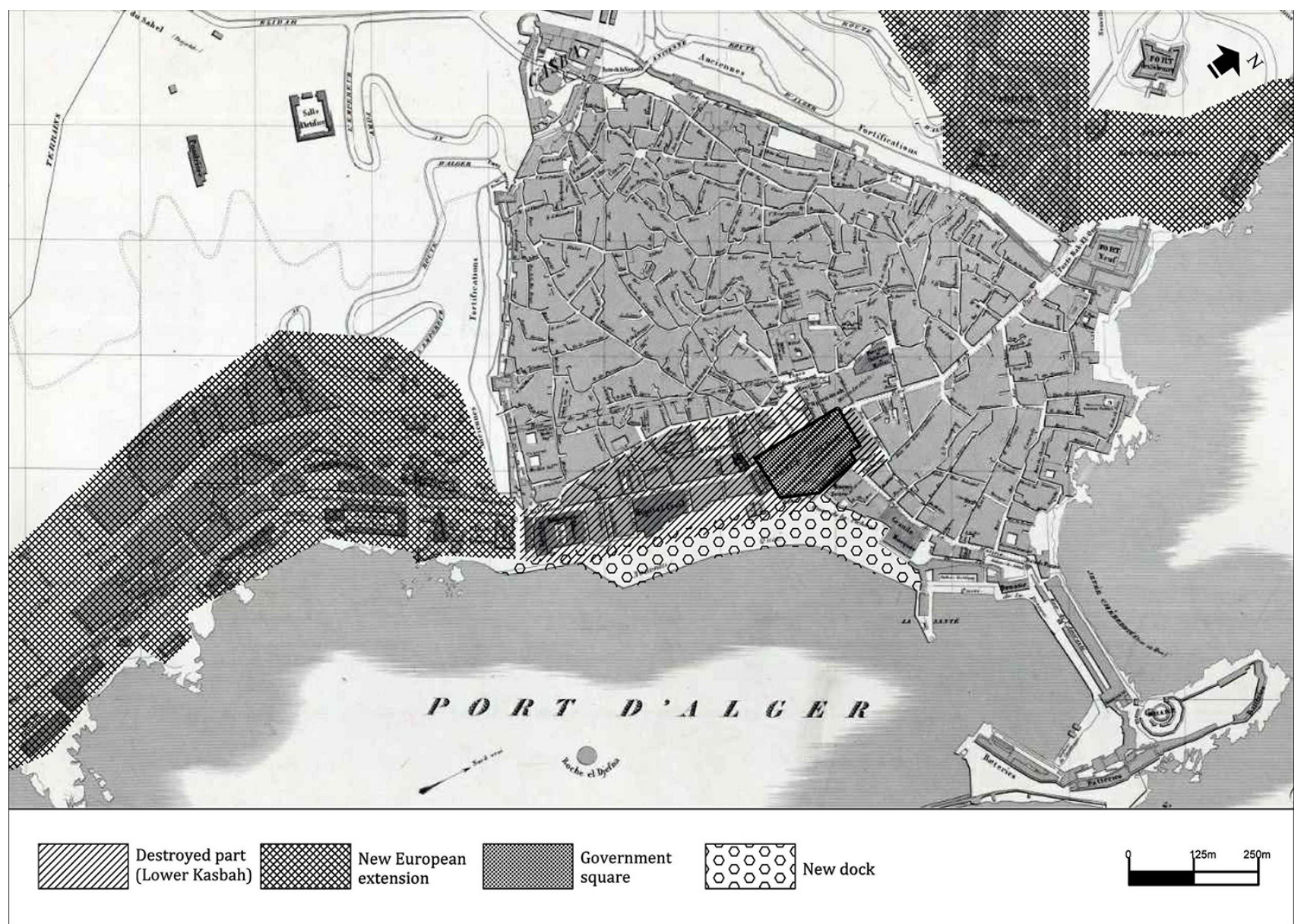

Figure 5. Map of Algiers in 1846. Source: Amended by the authors, based on Berbrugger (1846).

the resulting trade revenues were being invested in the construction industry (Lespès, 1921). This shows that the development of the port continued to simultaneously influence the development of the city. In addition, the opening of the Suez Canal in 1869 made Algiers an unavoidable transfer hub for liners arriving from the North Sea or the Atlantic. The strongly increased traffic became increasingly more difficult for the port to absorb. Therefore, by law of 25 June 1897, the Chamber of Commerce in Algiers was granted the permission to increase the port's capacities through a set of expansion projects (Lespès, 1921).

The aforementioned set of economic events opened up new prospects for the port city of Algiers, thereby changing its predominant vocation from a military into a tertiary hub. Accordingly, the port was significantly enlarged: to the previous basin of the old port (1848-1867), two new ones were created and added, namely the Agha (1898-1905) and Mustapha basins (1927-1940; Djedouani-Rakem, 2004). At the same time, the development of the port continued to stimulate the urban growth of the city (Djedouani-Rakem, 2004). On the other hand, however, Lespès (1921) argues that it is already around 1884 that the transformation of Algiers from a military city into an important tertiary centre must be situated, notably thanks to the major railway developments at the time (new connections between Algiers-Constantine [1887]; Algiers-TiziOuzou-Béjaïa [1890]; Algiers-Blida-Berrouaghia [1892]). A strong connectivity with the hinterland and its flows of goods was indeed developed thanks to these new railway connections. Furthermore, the linear development of the port towards the east stimulated the extension of the city in the same direction, thereby giving rise to a mixed urban fabric of housing and small industries linked to port activities in the neighbourhoods El-Hamma and Hussein-Dey that further concretised the new port-city interface.

Faced with this fundamental change from a military to a transfer city, the port-city interface started to take on a new spatial configuration that was adapted to the new flows that it supported. The interface evolved from a rather open space, ensuring relative reciprocity between port and city, to a denser zone through which spatial limitations between the city and the port materialised. A situation similar to that of the classic port-city split described earlier became increasingly noticeable from this period onwards (Aouissi \& Madani, 2017). The rising dichotomy became especially accentuated by the piling up of industrial activities that distanced the new urban extensions, particularly on the side of El-Hamma and Hussein-Dey, from the port and the sea. Within this context, the 
interface continued to develop in a two-dimensional way: longitudinally, following the extensions of the port and thus mostly guiding the colonial city's development towards the southeast; and transversally, according to the needs of flows of goods and thereby especially linking the port to the colonial hinterland through an extended railway network. With this new morphological configuration of the port-city interface in mind (see Figure 6), the first steps of a shift between port and urban development could be traced. If the port had guided the urbanisation of Algiers up to that point, the dichotomy created by the interface's rigidity and the growing physical distance between both entities now started to cause a new development rhythm, one characterised by a shrinking sense of porosity in Algiers' overarching evolution. While the port continued its expansion further towards the southeast, the city, on the other hand, started to pursue its path of urbanisation more towards the inland and the adjacent hilltops.

\subsection{The Interface of the National Capital (1962-Present)}

After gaining independence, Algiers became the national capital due to its geostrategic, economic, and relay location. This status was quickly reinforced, especially after the nationalisation of the hydrocarbon industry in 1971 (Leroux, 2018). Up until today, Algeria's economy is mainly based on the export of hydrocarbons and the import of almost all consumer goods and products, and the port of Algiers is still considered as the nation's principal commercial port (Entreprise Portuaire d'Alger, 2019). In this contemporary context, the port-city interface has become more complex, expressing a superposition of urban and port interests in one conflicting space. Interests related to life quality in the modern metropolis are juxtaposed with concerns over economic efficiency in the face of strong competitiveness on the national and Mediterranean level. In the midst of this duality, the interface has become the autonomous space of a very pronounced port-city divide, physically limiting and separating both city and port, but also providing support for common flows (Aouissi, 2019). Currently, it is possible to identify four spatial sequences of the interface, which connect and correspond to the differing rhythms of the city's and port's evolution that we have investigated. Each of these sequences has a distinct composition, and together they illustrate the significant expansion of the port-city interface over time (see Figures 7 and 8). In correspondence with this historical growth in scale, the interface is nowadays no longer considered as some kind of no man's land, as it often had been in the past, but rather as a true asset for future municipal planning projects. In order to better understand Algiers' multifaceted interface, Table 1 describes its different, present-day states through characteristic cross-sections and porosity-related variables.

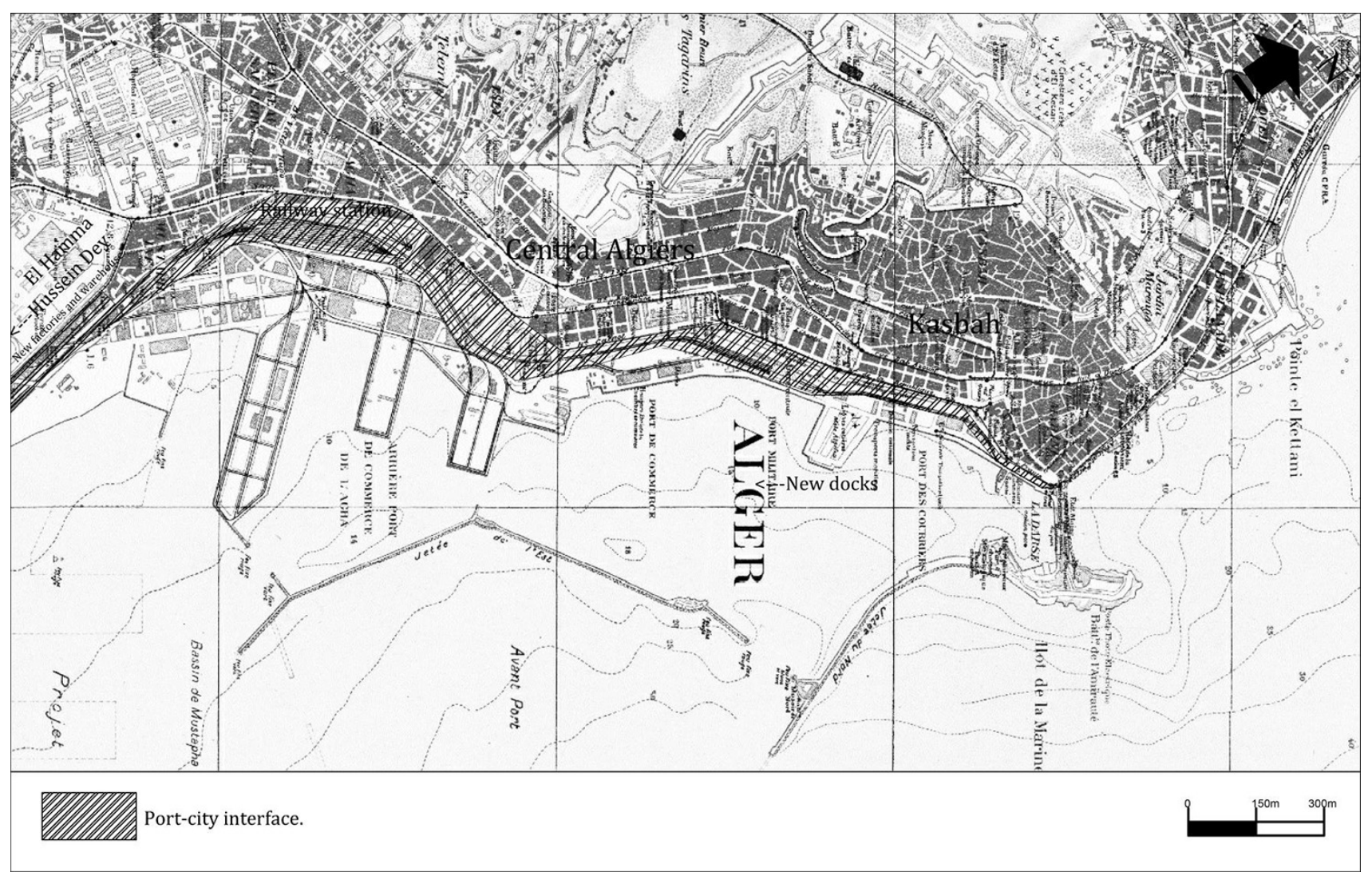

Figure 6. Map of Algiers in 1925, accentuating the structure of the port-city interface. Source: Amended by the authors, based on Farnet (1925). 


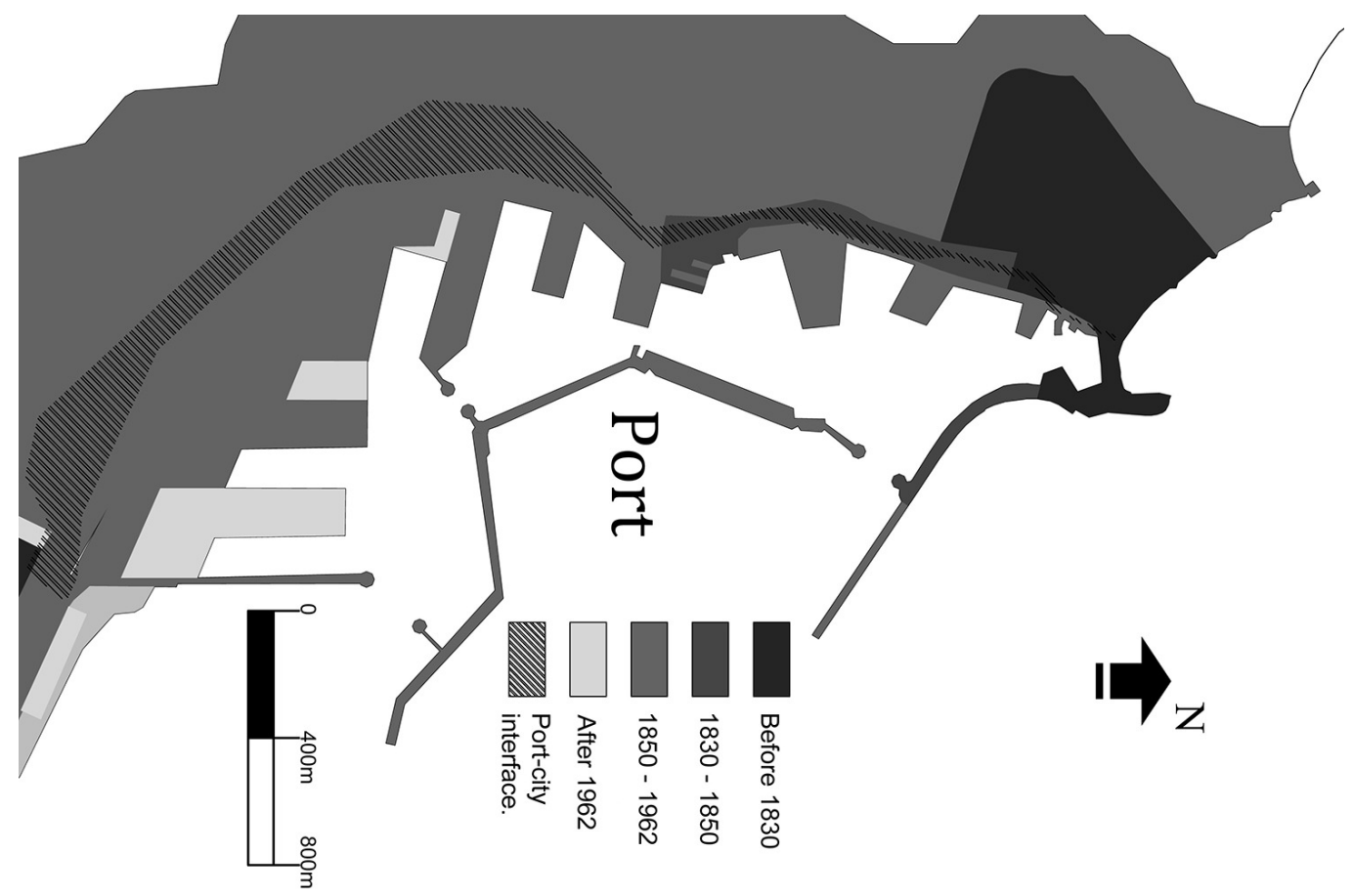

Figure 7. Diagram of Algiers' current port-city interface, divided according to its morphological evolution. Source: Produced by the authors, based on Google Earth with the distinctions of the different periods visualised in accordance with Hammache et al. (2000).

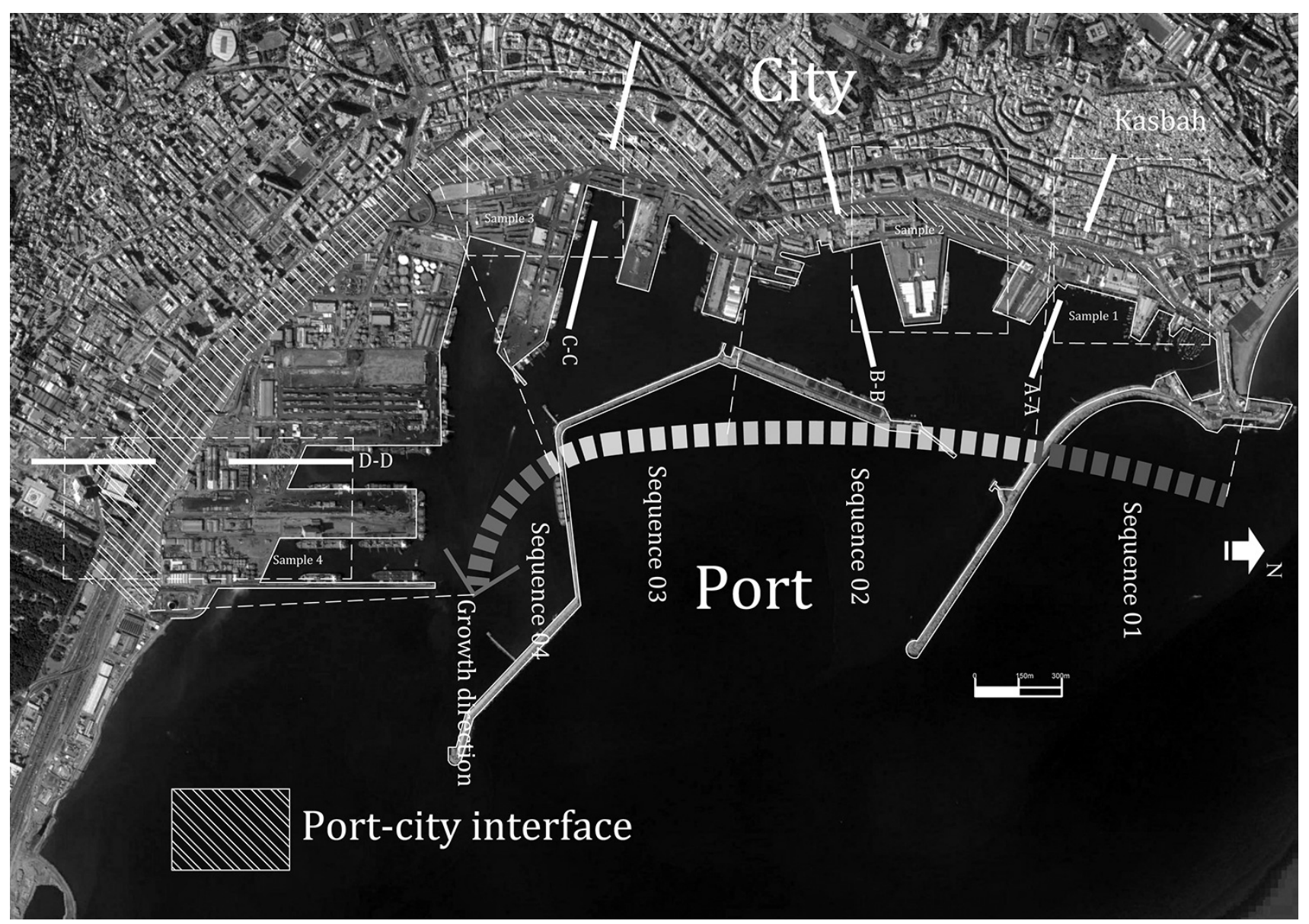

Figure 8. Map of Algiers' current port-city interface, divided in relevant sequences with cross-sections. Source: Google Earth and modified by the authors. 
In addition to the information displayed for each interface sequence in Table 1, we can interpret the variations in the ratios of the void spaces to the total linear contact with the urban walls as a consequence of the intentions and perception of the responsible planning actors during each corresponding historical period. In the first sequence, the urban fabric is composed of an alignment of small building blocks, in accordance with the existing pre-colonial fabric of the Kasbah. This expresses a significant potential for porosity and permeability, which would allow further control over the flows between city and port through materialised connections like footbridges. The second sequence expresses an even higher level of porosity, through an opening up of the urban fabric and continuity by means of footbridges from the sloping site of the city. The third and fourth sequences, on the other hand, express very weak levels of porosity. As these sequences are the products of the final colonisation phase and of the post-independence period, their opaque character testifies of the consistent preference of past port authorities regarding the planning of extra port extensions and the corresponding management of flows within an industrial landscape. In this respect, it is no surprise that the port-city interface has long been considered no man's land until now. Therefore, the aim nowadays is to take back the port-city interface, so to speak, and to substantially include it in Algiers' urban planning, in order to reweave the links between city, port, and sea.

Table 1. Different sequences of Algiers' current port-city interface.

Satellite views with schematic cross-sections and porosity Interface descriptions studies

Sample 1:
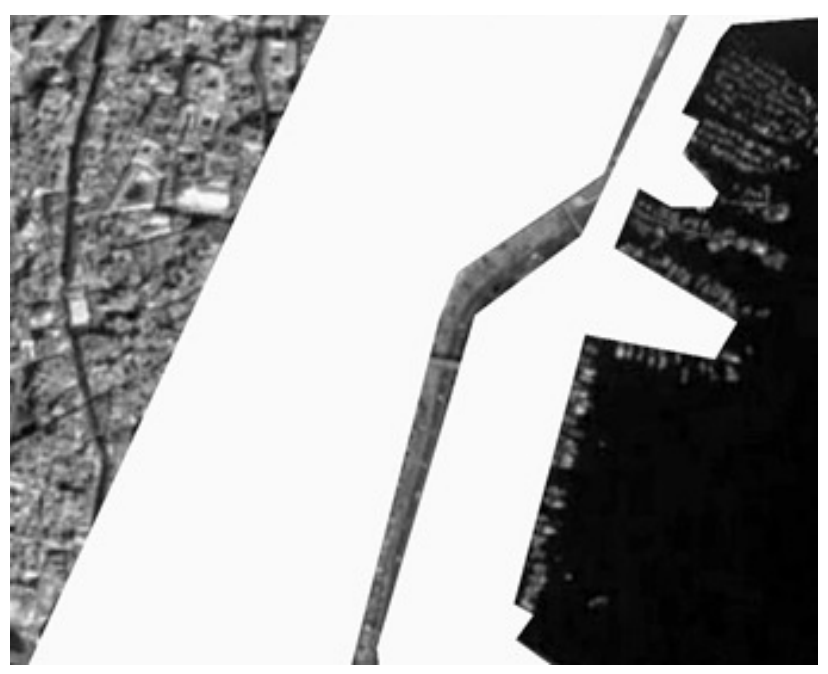

Section A-A:

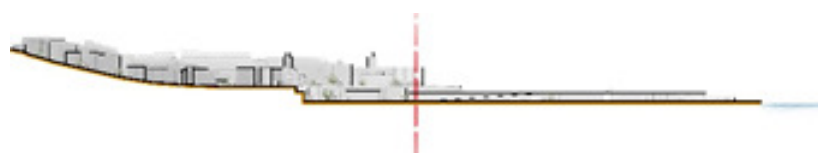

Porosity study:

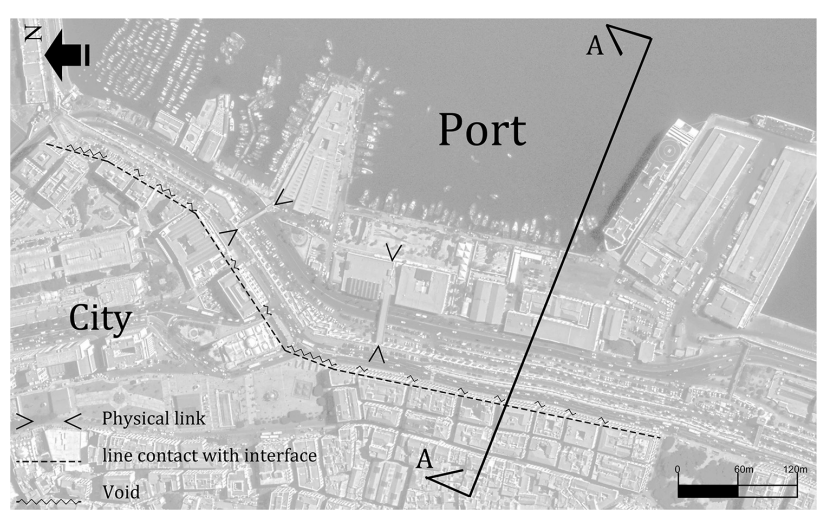

Sequence 1:

The first part of the interface is connected to the origin of the port that dates back to the Ottoman period. It is adjacent to the historical part of the Kasbah and was adopted as a fishing port.

The sloping site of the city and the reduced thickness of the interface, which is mainly composed of roads here, provides a certain visual transparency in the surrounding landscape. Although the fishing port is fenced and remains difficult to access, the presence of fishing activities and some nearby restaurants maintain the link between city and port in this area.

Porosity-related characteristics:

Physical links: 2

Line contact with interface $\approx 720 \mathrm{~m}$

Void $\approx 217 \mathrm{~m}$

Void ratio $=0,30$ 


\section{COGITATIO}

Table 1. (Cont.) Different sequences of Algiers' current port-city interface.

Satellite views with schematic cross-sections and porosity studies

Sample 2:

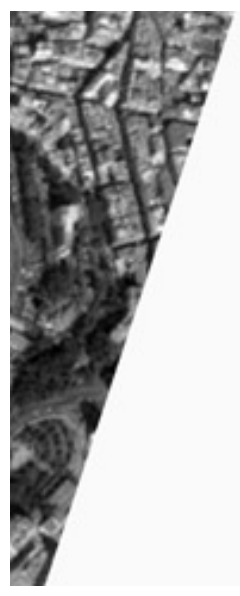

Section B-B:

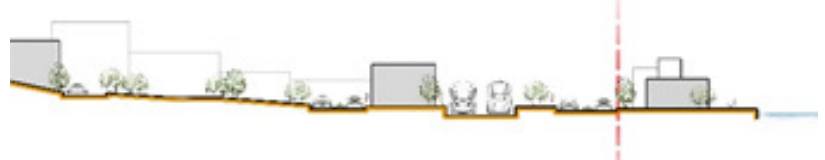

Porosity study:

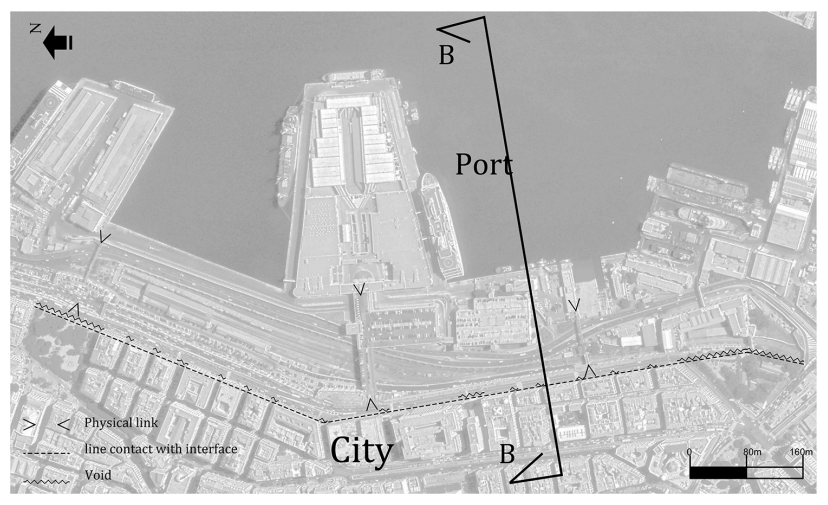

Interface descriptions

Sequence 2:

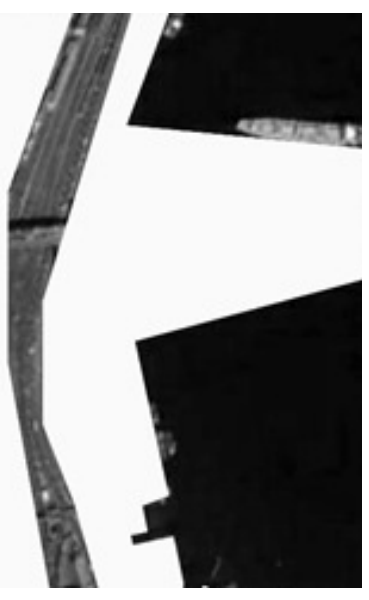

The second sequence contains the first extramural urban extensions. Here, the port area goes back to the time of the military use of the port. Today, after the creation of several quays at the end of the 19th and beginning of the 20th century, it includes the Algiers Maritime Station.

This site has a continuously descending shape. At a lower height, the footbridge of the Maritime Station provides a clear form of connectivity between the city and the port. On the other hand, the thickness of the interface increases here, through the stacking of mechanical and railway tracks.

Porosity-related characteristics:

Physical links: 3

Line contact with interface $\approx 1300 \mathrm{~m}$

Void $\approx 520 \mathrm{~m}$

Void ratio $=0,40$ 
Table 1. (Cont.) Different sequences of Algiers' current port-city interface.

Satellite views with schematic cross-sections and porosity Interface descriptions studies

Sample 3:

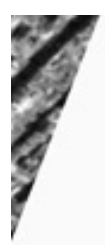

\section{党}

Section C-C:

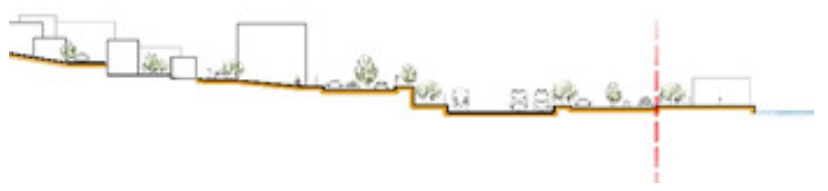

Porosity study:

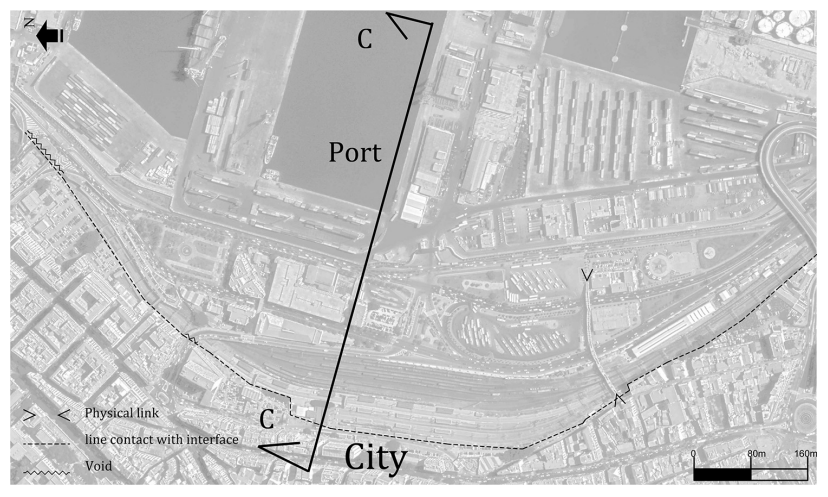

\section{Sequence 3:}

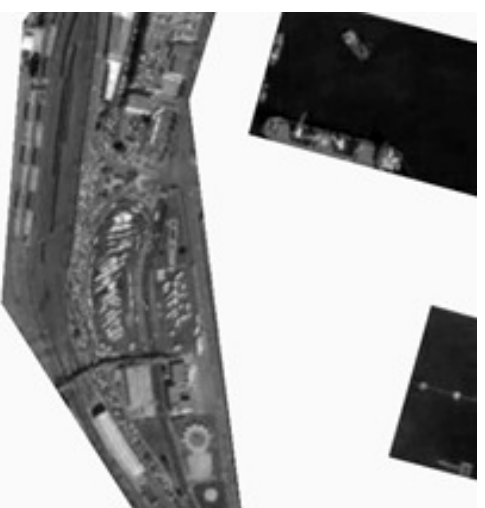

This sequence includes the most recent extensions of the port, built by the colonial authorities just before Algeria's independence.

Here, city and port are at the same height level, and the interface takes up a more significant width. The interface becomes more dynamic at this section, due to the strong presence of mechanical tracks and the railway and land station. However, fewer direct connections between city and port are established here.

Porosity-related characteristics:

Physical links: 1

Line contact with interface $\approx 1400 \mathrm{~m}$

Void $\approx 103 \mathrm{~m}$

Void ratio $=0,07$ 
Table 1. (Cont.) Different sequences of Algiers' current port-city interface.

Satellite views with schematic cross-sections and porosity Interface descriptions
studies

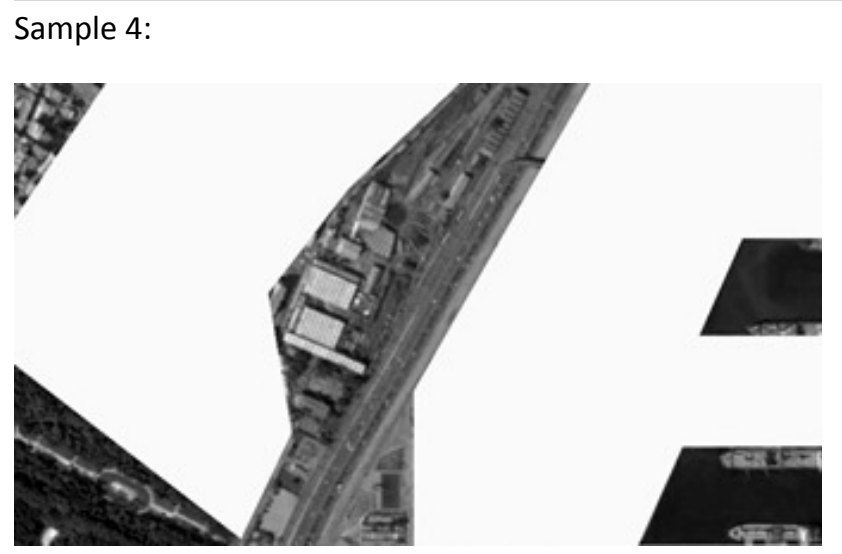

Section D-D:

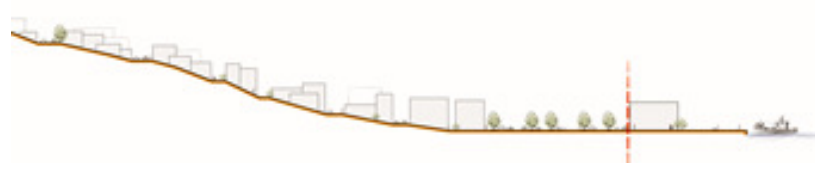

Porosity study:

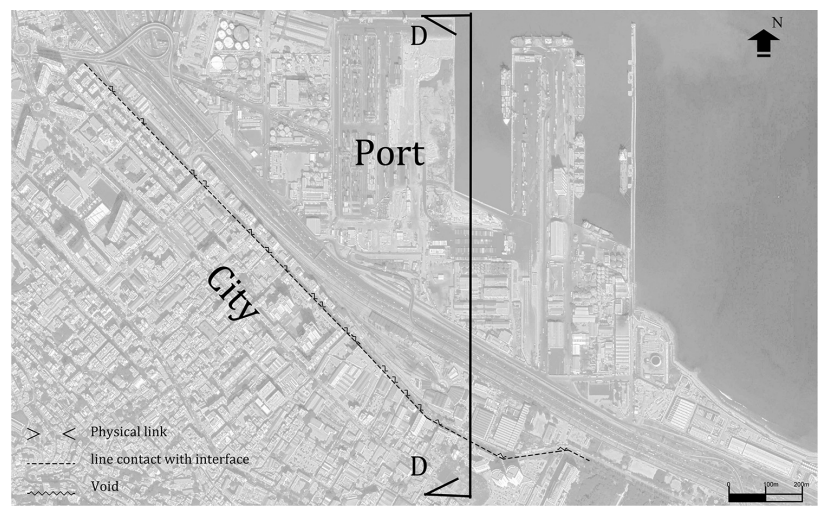

Sequence 4:

After independence, local authorities continued within the same framework of industrialisation that the colonial powers had previously set up. This currently results in the most recent phase of the port's development, which is also the most commercially significant, as it includes a major container terminal, oil terminal and wheat storage silos.

Staying at the same height level, the thickness of the interface persists here. The width exceeds $300 \mathrm{~m}$ in certain places, and its physical dominance is reinforced by the presence of warehouses and industrial wastelands. A close connection with the port and waterfront is absent. In terms of flows of goods, it can nevertheless be considered as the most dynamic part of the interface, since it forges direct access to the contemporary centre of Algiers. Porosity-related characteristics:

Physical links: 0

Line contact with interface $\approx 1820 \mathrm{~m}$

Void $\approx 250 \mathrm{~m}$

Void ratio $=0,13$

Notes: Source of processed satellite images and cross-sections: Aouissi (2019). Porosity studies by the authors.

\section{Conclusion}

Through an analysis of the long-term evolution of its port-city interface, the case of Algiers shows that this median space is much more than merely a buffer zone that articulates and limits the spatial contours of the port. The often technical evolution of the port city's flows has contributed to the increasing complexity, fluctuating porosity, and dynamic mutation of the interface over time, from a rather strictly amalgamated space between city and port into an intricate support structure for incoming and outgoing flows of goods. Our study of the interface's morphological evolution has made it possible to both understand the synchronic structuring between port and city, and the diachronic development of the interface itself, which ultimately turns out to be a non-homogeneous spatial entity composed of four distinct sequences with differing porosity profiles.
The presented work on Algiers' interface can be decisive for a better and more nuanced understanding of the relationship between city, interface and port. This directly contributes to a better orientation of imminent waterfront revitalisation processes in and around the bay of Algiers, as foreseen in the city's 2016 Master Plan (Aouissi, 2019; Wilaya d'Alger, 2016). Today, the interface is considered as the quintessential spatial concretisation of Algiers' port-city split (Aouissi \& Madani, 2017), not only by researchers, but also by local port authorities and municipal actors. The municipal government's 2016 Master Plan aims to turn the interface into a tool of reconciliation, however, as the driving force of envisioned urban planning operations. Through this prism of urban renewal, the planned interventions on the interface will enable the city of Algiers to acquire more than 58 hectares of additional land, both in the heart of the city centre and on the waterfront. This opens up a variety 
of new urban development possibilities and porosityrelated improvements within the four different interface sequences distinguished in this study, which we briefly want to highlight further.

Interventions in the first interface sequence can allow to more strongly connect the Kasbah's heritage fabric with the port. The second sequence, essentially composed of mechanical and railway tracks, can easily be reconfigured by the municipality to further exploit the descending shape from the city to the port, in particular through the existing pedestrian bridge that currently remains inactive because of safety reasons. The third and fourth sequences take up an extended width between 100 and $300 \mathrm{~m}$ and thus offer the possibility for new planning projects to break free from the traditional rigidity of the interface (Hayuth, 1982), by acting upon its potential porosity and permeability instead. The initiation of projects in these parts of the interface can make it possible to constitute a more elaborate built environment by the waterfront, in order to enhance the links between city, port, and sea (Yang, 2006).

Port spaces, functions, and interests have shaped the growth and development of many port cities across the world (Hein \& Schubert, 2021). This is also confirmed in the previously neglected case of Algiers, especially when considering the four different sequences that we have now identified for its current port-city interface. Born from a tumultuous, centuries-long history, the multifaceted characterisation of Algiers' interface nowadays shows how the city's development has only followed that of the port, even if they were strongly spatially separated over time. It should be emphasised that the findings and results arising from this historical examination can be considered in a more general sense and potentially extrapolated to other port city contexts, especially those on the west side of the southern Mediterranean shore. Port cities like Casablanca, Tangiers, Oran, Béjaïa, Annaba, and Tripoli also did not experience an industrial revolution during the 19th century, but rather a colonisation movement that remains the origin of the port-city divide experienced in these cities today. The case of Algiers shows that within such a context an indirect relation between city and port still persists, which the interface can well help to further weave together and reinforce through new reconversion projects. As these prospects present themselves as necessary interventions for tackling Algiers' port-city split, their future implementation hopefully acknowledges the intricate profile of the port-city interface, in order to put Algiers on a successful course towards sustainable processes of waterfront revitalisations.

\section{Acknowledgments}

We would like to express our gratitude to the Laboratory PUViT (Projet Urbain, Ville et Territoire) at Ferhat Abbas University Setif 1, Algeria, for the elaboration of this manuscript. We would like to thank the Erasmus School of History, Culture and Communication at Erasmus University Rotterdam for its support.

\section{Conflict of Interests}

The authors declare no conflict of interests.

\section{References}

Akhavan, M. (2020). Port geography and hinterland development dynamics: Insights from major portcities of the Middle East. Springer. https://doi.org/ 10.1007/978-3-030-52578-1

Aouissi, K. B. (2016). Le clivage ville/port: Le cas d'Alger [The port-city divide: The case of Algiers]. Connaissances et Savoirs.

Aouissi, K. B. (2019). Alger; Prospection d'une reconversion portuaire comparée [Algiers: Prospects for a port reconversion compared] [Doctoral dissertation, Ferhat Abbas University Setif 1].

Aouissi, K. B., \& Madani, S. (2017). Alger: Prospection de scénarii pour sa reconversion portuaire [Algiers: Prospecting a set of scenarios for its waterfront revitalisation]. Cinq Continents, 7(16), 151-172.

Belhamissi, M. (1986). Histoire de la marine algérienne (1516-1830) (2nd ed.) [Naval history of Algeria (1516-1830)]. Entreprise Nationale du Livre.

Bérard, A. (1837). Description nautique des côtes de l'Algérie [Nautical description of the coasts of Algeria]. Imprimerie Royale.

Berbrugger, A. (1846). Plan général de la ville d'Alger et de ses faubourgs [General city map of Algiers and its suburbs] [Map]. Dubos Frères \& Marest. https:// gallica.bnf.fr/ark:/12148/btv1b53088061c

Bernard, A. (1931). Alger, étude de géographie et d'histoire urbaines [Study of Algiers' urban geography and history]. Annales de Géographie, 40(224), 202-204.

Bird, J.-H. (1963). The major seaports of the United Kingdom. Hutchinson.

Boubacha, E. (1997). L'interface ville/port: Espacesystème en mutation, l'exemple de Nantes [The port-city interface: Changing spatial system, the case of Nantes] [Postgraduate thesis, University of Nantes].

Boubacha, E., Davoult, D., \& Gueguen, E. (1997). Ville et port, mutation et recomposition: Note de synthèse et bibliographie [City and port, change and restructuring: Summary and bibliography]. Les Editions Villes \& Territoires.

Braudel, F. (1949). La Méditerranée et le monde méditerranéen à l'époque de Philippe II [The Mediterranean and the Mediterranean world in the time of Philip II]. Librairie Armand Colin.

Camps, G., Leglay, M., Golvin, L., Mantran, R., \& Boyer, P. (1986). Alger [Algiers]. Encyclopédie Berbère, 4, 447-472.

Çelik, Z. (1997). Urban forms and colonial confrontations: 
Algiers under French rule. University of California Press.

Chaline, C. (Ed.). (1994). Ces ports qui créèrent des villes [These ports that created cities]. L'Harmattan.

Chaline, C. (1999). La régénération urbaine [Urban regeneration]. Presses Universitaires de France.

Chérif, B. A. (2010). Les colonies portuaires espagnoles au Maghreb du XVI ${ }^{\mathrm{e}}$ au $\mathrm{XX}^{\mathrm{e}}$ siècle [The Spanish port colonies in the Maghreb from the 16th to the 20th century]. Insaniyat: Revue Algérienne d'Anthropologie et de Sciences Sociales, 2010(47/48), 159-191. https://doi.org/10.4000/insaniyat.4973

de Haëdo, D. (1998). Topographie et histoire générale d'Alger [Topography and general history of Algiers]. Editions Bouchène. (Original work published 1612)

Djedouani-Rakem, S. (2004). Mutations urbaines et stratégies de renouvellement dans deux villes-ports méditerranéennes: Le cas de Marseille et Alger [Urban changes and renewal strategies in two Mediterranean port cities: The case of Marseille and Algiers] [Doctoral dissertation, University Paris XII].

Entreprise Portuaire d'Alger. (2019). Rétrospectives des trafics portuaires, port d'Alger, periode: 2012/2019 [Retrospectives of port traffic, port of Algiers, period: 2012-2019].

Farnet, E. (1925). Carte d'Alger [Map of Algiers] [Map]. E. Chiron. https://gallica.bnf.fr/ark:/12148/ btv1b53192690z

Hall, P. V., \& Jacobs, W. (2010). Shifting proximities: The maritime ports sector in an era of global supply chains. Regional Studies, 44(9), 1103-1115. https:// doi.org/10.1080/00343400903365110

Hammache, S., Chennaoui, Y., Aït Cherkit, S., \& Sidi Moussa, L. (Eds.). (2000). Alger métropole: Région-ville-quartier [Metropolis Algiers: Regioncity-district]. EPAU and SIAAL.

Hayuth, Y. (1982). The port-urban interface: An area in transition. Area, 14(3), 219-224.

Hein, C. (Ed.). (2020). Adaptive strategies for water heritage: Past, present and future. Springer. https://doi. org/10.1007/978-3-030-00268-8

Hein, C., \& Schubert, D. (2021). Resilience and path dependence: A comparative study of the port cities of London, Hamburg, and Philadelphia. Journal of Urban History, 47(2), 389-419. https://doi.org/ $10.1177 \% 2 F 0096144220925098$

Hoyle, B. (2000). Global and local change on the port-city waterfront. Geographical Review, 90(3), 395-417. https://doi.org/10.1111/j.1931-0846.2000.tb00344.x

Hoyle, B. S. (1989). The port-city interface: Trends, problems and examples. Geoforum, 20(4), 429-435. https://doi.org/10.1016/0016-7185(89)90026-2

Hoyle, B. S., \& Pinder, D. A. (Eds.). (1992). European port cities in transition. Belhaven Press.

Hoyle, B. S., Pinder, D. A., \& Husain, M. S. (Eds.). (1988). Revitalising the waterfront: International dimensions of dockland redevelopment. Belhaven Press.

Jacob-Rousseau, N. (2009). Géohistoire/géo-histoire:
Quelles méthodes pour quel récit? [Geohistory/ geo-history: Which methods for which story?]. Géocarrefour, 84(4), 211-216. https://doi.org/10.4000/ geocarrefour.7598

Leroux, S. (2018, February 24). Ce jour-là: Le 24 février 1971, Houari Boumédiène annonce la nationalisation des hydrocarbures [That day: On 24 February 1971, Houari Boumédiène announces the nationalisation of hydrocarbons]. Jeune Afrique. https:// www.jeuneafrique.com/534985/politique/ce-jourla-le-24-fevrier-1971-houari-boumediene-annoncela-nationalisation-des-hydrocarbures

Lespès, R. (1921). Le port d'Alger [The port of Algiers]. Annales de Géographie, 30(165), 195-222.

Meunier, R. (1961). La darse des Turcs d'El-Djezaïr [The dock of the Turks of El-Djezaïr]. Les Feuillets d'El-Djezaïr, 3, 3-10.

Missoum, S. (2003). Alger à l'époque Ottomane: La médina et la maison traditionnelle [Algiers in the Ottoman era: The medina and the traditional house]. Edisud.

Moretti, B. (2018). The urban-port threshold: Models and strategies. In L. Pedata, E. Porfido, \& L. Rossi (Eds.), (Co)habitation tactics: Imagining future spaces in architecture, city and landscape (pp. 535-543). POLIS University.

Porfyriou, H., \& Sepe, M. (Eds.). (2017). Waterfronts revisited: European ports in a historic and global perspective. Routledge.

Ravéreau, A. (2007). La Casbah d'Alger, et le site créa la ville [The Kasbah of Algiers: And the site created the city]. Actes Sud.

Sánchez, J. M. P., \& Daamen, T. A. (2020). Using heritage to develop sustainable port-city relationships: Lisbon's shift from object-based to landscape approaches. In C. Hein (Ed.), Adaptive strategies for water heritage: Past, present and future (pp. 383-399). Springer. https://doi.org/10.1007/978-3030-00268-8_20

Schubert, D. (2018). Ports and urban waterfronts. In C. Hein (Ed.), The Routledge handbook of planning history (pp. 336-347). Routledge.

Tan, T.-Y. (2007). Port cities and hinterlands: A comparative study of Singapore and Calcutta. Political Geography, 26(7), 851-865. https://doi.org/ 10.1016/j.polgeo.2007.06.008

Wilaya d'Alger. (2016). Plan directeur d'aménagement et d'urbanisme [Master Plan for urban development and planning].

Wrenn, D. M. (1983). Urban waterfront development. Urban Land Institute.

Yang, D. (2006). Waterfronts: Spatial composition and cultural use [Doctoral dissertation, University College London].

Zimmermann, M. (1896). La colonisation de l'Algérie: Le port d'Alger [The colonisation of Algeria: The port of Algiers]. Annales de Géographie, 5(21), 344-345. 


\section{About the Authors}

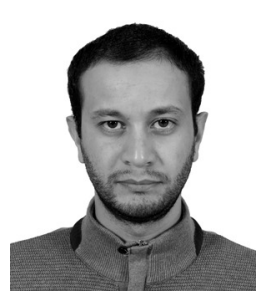

Khalil Bachir Aouissi is an Architect, holds a PhD in Architecture and Urban Design, and is a Researcher in the Laboratory PUViT at Ferhat Abbas University Setif 1 in Algeria. He is a Professor in Architecture and Urban Design, Member of the Scientific Council of the Institute of Architecture and Urbanism, and Head of the Department of Architecture at the Blida 1 University, Algeria. His current field of research is mainly concerned with urban forms and port cities.

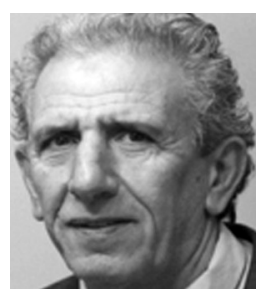

Said Madani is Prof. Dr. Arch., and Head of the Laboratory PUViT at Ferhat Abbas University Setif 1 in Algeria. He is a Member of the Scientific Council of the Institute of Architecture and Earth Sciences. Teaching Architecture and Urban Design, his area of interest includes the design process for the production of the built environment. His current research focuses on the transfer of architectural and urban knowledge, with a particular emphasis on urban public space and port cities.

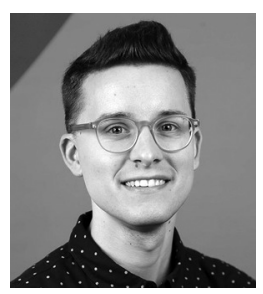

Vincent Baptist is a PhD Candidate in the Erasmus School of History, Culture and Communication at Erasmus University Rotterdam, and is affiliated with the Leiden-Delft-Erasmus research consortium PortCityFutures. His doctoral research is embedded in the international HERA project "Pleasurescapes: Port Cities' Transnational Forces of Integration." He has previously worked in the digital humanities research program CREATE at the University of Amsterdam. 